JOURNAL OF FINANCIAL AND QUANTITATIVE ANALYSIS

Proceedings Issue - November 1978

ANNOUNCEMENT

CALI FOR PAPERS AND PARTICIPANTS

1979 Western Finance Association Annual Meetings

June $21-23,1979$

San Francisco, California

The Annual Meetings of the Western Finance Association will be held June $21-23$ at the Ramama Inn at Fisherman's Wharf in San Francisco. This will be the 14 th annual conference of the Western Finance Association, and the first time the organization has met independently of the Western Economic Association. Members and friends of the Association are invited to submit papers for presentation at the meetings. Suggested topics include:

Theory of Finance

Efficient Capital Markets, and Evidence

Financial Intermediation, Theory and Evidence

Financial Markets, structure and Requlation

Financial Institutions, Structure and Regulation

Investments and Portfolio Analysis

Behavior of Securities Process:

--Equity securities

-Fixed income securities

-Options and other securities

--Inflation and securities returns
Real Estate Finance

Risk Management and Insurance

International Finance

Monetary Policy and Practice

Mergers and Acquisitions

Multinational Finance

Managerial Finance:

--Corporate Financial Planning

--Corporate Financial Policies

--In the Not-for-Profit Sector

--In Regulated Environments

--In an Inflationary Environment

Content and Teaching of Finance

Courses

This list should not be considered exhaustive. Papers on other topics of interest to members of the Association are solicited and will be considered.

\title{
Submission of Papers
}

Four copies of either the completed paper or a five-page abstract, stating the problem, method, data, and implications of findings, should be sent to the Program Chairman no later than November 15, 1978. The papers will be reviewed by the Committee and the authors will be advised of their decision during December 1978 .

To maintain objectivity in selection, a separate cover sheet should be included to provide the following information:

1. Name

2. Position

3. Affiliation, mailing address and telephone number
4. Title of Paper

5. Categorization of Paper Topic (as above)

6. Willingness to serve as Discussant or session Chairman

Other Participants

othex persons who are willing to serve as Chairpersons or Discussants also are invited to submit the same information. In lieu of items 4 and 5, you should indicate your field(s) of interest in finance. 
All papers and communications pertaining to participation on the program should be sent by November 15, 1978 to:

Donald E. Farrar

School of Business

University of Utah

Salt Lake City, Utah 84112 


\title{
ANNOUNCEMENT
}

KENNETH L. TREFFTZ STUDENT AWARD

FOR AN OUTSTANDING PAPER IN FINANCE

The Western Finance Association invites Faculty members to submit student papers in the area of Finance to be considered for the annual KENNETH L. TREFFTZ AWARD. The competition is open to both graduate and undergraduate students.

Author of the selected paper will have an opportunity to present his or her paper at the 1979 Annual Meeting of the Western Finance Association in San Francisco. The paper will be published in the 1979 Proceedings Issue of the Journal of Financial and Quantitative Analysis. In addition, the award winner will receive a cash prize of $\$ 150$.

The subject matter of papers is not restricted to any specific area of Finance. Papers in business finance, investments, banking, and financial markets and institutions are especially appropriate. However, others in related areas such as insurance, accounting, etc., might also be acceptable if the paper has significant implications for Finance. Papers may be theoretical or empirical. Since the selected paper will be published in the Journal, papers should be of high quality and appropriate length for a journal article. All papers will be evaluated by the Awards committee. The comittee retains the right not to award the prize if the papers submitted fail to meet the quality requirements.

Students interested in having their papers considered for this Award should submit their papers in triplicate, not later than March 30, 1979, to:

\author{
Professor Seha M. Tinic \\ Faculty of Commerce \\ University of British Columbia \\ 2075 Wesbrook Ma11 \\ Vancouver, B.C., Canada V6T1W5
}

The winner of the Trefftz Award will be announced no later than May 15, 1979. 